\title{
4.14 Досвід та перспективи викладання хімічних дисциплін в умовах дистанційного навчання
}

За умови пандемії коронавірусу COVID-19 зручним та доступним способом отримання знань є дистанційна освіта. В 1997 року діяло близько 1000 навчальних закладів, що мали дистанційну форму навчання в 107 країнах світу i кількість осіб складала близько 50 млн. Кількість осіб, які отримали вищу освіту, використовуючи дистанційну форму навчанняв у 2000 року складала 90 млн, а у 2023 р. за прогнозами складатиме 120 млн осіб. У зв'язку з пандемією коронавірусу COVID-19 в Україні, як і в багатьох країнах світу, навчання студентів у нашому ВНЗ було переведено в онлайн-режим із застосуванням сучасних технологій дистанційного навчання [332,333].

Галузь вищої медичної (фармацевтичної) освіти була серед тих, що зазнала найбільшого впливу від пандемії [334-336], адже спілкування є необхідною умовою передачі знань та навичок від однісї людини до іншої [337]. Також, необхідно зазначити, що формування здобувачами освіти певних навичок можливе тільки за наявності спеціальних умов, зокрема спеціально обладнаних навчальних лабораторій та закладів охорони здоров'я, в яких реалізовано доступ студентів до пацієнтів тощо. Таким чином, співробітники закладів вищої освіти постали перед одним з найбільш серйозних викликів за всю новітню історію медичної та фармацевтичної освіти.

Отже метою роботи було узагальнення досвіду викладання хімічних дисциплін «Аналітична хімія» та «Фізична і колоїдна хімія» в умовах дистанційної форми освіти.

Аналітична хімія та фізична і колоїдна хімія відносяться до одних 3 найважливіших дисциплін, що вивчаються майбутніми фармацевтами в рамках їх природничо-наукової підготовки. Успішне засвоєння теоретичного матеріалу 3 цих хімічних дисциплін $є$ необхідною передумовою для вивчення таких навчальних дисциплін фармацевтичної підготовки як біохімія, фармацевтична хімія, фармакогнозія, токсикологічна хімія, фармакологія тощо. Додатково під 
час вивчення цих хімічних дисциплін у студентів формуються базові навички проведення експериментів за умови лабораторії. Важливість цих хімічних дисциплін для становлення майбутніх фахівців у галузі фармації студентам, що навчаються за спеціальністю «Фармація, промислова фармація» полягає ще і у тому, що названі дисципліни включено до структури іспиту «КРОК-1. Фармація». Як відомо до європейських стандартів освіти належать системний, контекстний, безперервний та компетентнісний підходи до якості освітянських процесів, що потребує облік усіх факторів, які впливають на навчальний процес. 3 метою забезпечення впровадження таких стандартів нами здійснюється методологічне i методичне обгрунтування i розробка організаційних технологічних підходів до методики викладання дисциплін.

3 початком карантинних обмежень в Дніпровському державному медичному університеті (ДДМУ) були затверджені єдині підходи до провадження навчальної роботи. Програмне забезпечення дозволяло організовувати відеоконференції, надавало можливість адресної видачи завдань та обліку відповідей студентів, планувати заняття у календарі, інтеграцію 3 іншими додатками тощо. Навчальний процес було реалізовано у синхронному режимі з повною візуалізацією навчального матеріалу.

Ефективність викладання хімічних дисциплін значною мірою залежить від якості візуалізації навчального матеріалу. Враховуючи зазначене доцільним $є$ використання в якості допоміжного програмного забезпечення редакторів хімічних формул та додатків, що дозволяють створювати тривимірні моделі молекул хімічних сполук. Демонстрація студентам моделей дозволяє значно полегшити пояснення такого матеріалу як геометрична та оптична ізомерія комплексних сполук, вплив просторової будови сполук на їх реакційну здатність та механізми хімічних перетворень.

Однією 3 основних проблем при викладанні хімічних дисциплін $є$ неможливість виконання студентами навчальних дослідів, що передбачені програмами дисциплін, які $є$ вкрай важливими для формування практичних навичок. Неможливість проведення лабораторних робіт частково було 
компенсовано демонстрацією студентам навчальних відеоматеріалів, в яких здобувачам вищої освіти представлено виконання досліду 3 детальним поясненням суті хімічних перетворень. Для покращення підготовки студентів провізорів нами складено крім програм з вищезазначених хімічних дисциплін, базу тестових завдань для підготовки до ліцензійних іспитів «Крок-1» в системі «moodle», для комп’ютнрних класів створені тестові завдання для контролю навчального матеріала по темам дисциплін, підсумкові тестові завдання за дисципліною за навчальний рік, комплексні тестові завдання за декількох дисциплін, надруковано вісім навчально-методичних посібників. Вагомий внесок у якісну підготовку студентів - провізорів вносять сучасні комп'ютерні технології - сайт кафедри, на якому розташовані: інформація про порядок навчального процесу, плани, методичні розробки лекцій, практичних занять, самостійної роботи, теми для індивідуальної роботи, рекомендована література для самопідготовки, лекції в системі «Google Meet» i багато іншого. Така інформація полегшує підготовку студентів.

Наразі франкомовні студенти теж засвоюють нову для них методику проведення лекційних та практичних занять - за допомогою онлайн-технологій. Проте, використання вищезазначеного сервісу у студентів-іноземців має певні особливості: вони потребують більше часу, а подекуди і детальних покрокових інструкцій для правильного виконання завдань, багато студентів не бажають самостійно здобувати знання, або вимагають від викладача спрощення завдань. У багатьох із них є проблеми із дотриманням розпорядку: вони не з'являються в мережі у час проведення занять, вимагають консультацій викладача у вечірній час чи у вихідні дні.

Враховуючи труднощі в засвоєнні франкомовними студентами навчального матеріалу, пов’язані з наявністю мовного бар’єра, недостатнім забезпеченням навчальною літературою, іноді низькою мотивацією до навчання студентів, недостатнім рівнем початкової підготовки на батьківщині, особливу увагу проведення занять для студентів-іноземців спрямовуємо на вдосконалення процесу отримання і засвоєння знань, формування практичних вмінь і навичок. 
Для вирішення цих проблем колективом кафедри створені комплекси навчально-методичного забезпечення самостійної i аудиторної роботи українською, російською, англійською та французькою мовами. Постійне оновлення вказаних комплексів із використанням найсучаснішого навчального матеріалу є шляхом до оптимізації та удосконалення роботи 3 іноземними громадянами.

Враховуючи недостатні знання хімічної термінології українською мовою для франкомовних студентів створені посібники на французькій мові, що є синхронними посібникам українською мовою.

Важливою формою організації навчального процесу є лекція, як процес забезпечення орієнтовної основи для подальшої навчальної діяльності студентів в ході практичних занять. Усі лекції щорічно оновлюємо сучасними досягненнями науки, методично вивірюємо, науково обгрунтовуємо для кращого розуміння та сприйняття. А для поліпшення сприйняття лекційного матеріалу іноземними студентами матеріал надаємо в стислій формі, розглядаємо конкретні, загальноприйняті питання та терміни та забезпечуємо консультації лектора, якщо студентам незрозуміло щось із наданого матеріалу. Для покращення засвоєння матеріалу активно використовуємо сучасні мультимедійні засоби, які дають змогу представити схеми, діаграми, таблиці, окремі тези, що є основою для подальшого вивчення фармацевтичних дисциплін в ході професійної підготовки іноземних громадян.

Перспективним напрямком розвитку навчального процесу для іноземних громадян може стати створення альбомів для практичних занять, які містять необхідний навчальний матеріал у вигляді відповідних схем, таблиць, ілюстрацій, що сприяє розвитку моторної і зорової пам'яті студентів, активізує пізнавальну діяльність, допомагає сформвати зацікавленість предметом. Цілком можливо, що дані видання допоможуть вирішити одну з основних проблем пов'язаних 3 протиріччям між об'ємом навчального матеріалу та часом проведення заняття, що є найбільш актуальним саме в групах іноземних студентів. 
Студенти - провізори активно беруть участь у науковій роботі кафедри, представляючи свої наукові роботи на Всеукраїнських та міжнародних студентських конференціях. Так, за останні три роки виступили 13 іноземних студентів -провізорів зі доповідями своєї наукової діяльності.

Побудова педагогічного процесу на основі прозорості оцінювання студентів - провізорів формує довірливе ставлення студента до викладача, стимулює процес більш наполегливого отримання знань. Менші можливості мати під рукою необхідну літературу надає важливість самостійної підготовці студента. На допомогу йому - організація самостійної роботи студента за допомогою підручників, методичних видань, розроблених кафедрою за складними, важкими для освоєння тем, робота в бібліотеці з електронними ресурсами, підручниками та періодичними фармацевтичними виданнями.

Оснащення кафедри комп'ютерними класами, повсюдний доступ мережі «інтернет» полегшує контроль за самостійною роботою студента, сприяє різноманітності їі форм і підвищує ефективність, робить можливою підготовку студентів до ліцензійних іспитів «Крок-1». Слід зазначити, що робота з базою тестових завдань «Крок-1» $є$ обов'язковою, що сприяє концентрації уваги студентів на ключові закономірності хімічних дисциплін, дозволяє перевірити свої знання, адаптує до майбутнього ліцензуванню в країнах світу, де вони, можливо, будуть працювати.

Ми намагаємося робити все для того, щоб наші студенти в повному обсязі придбали знання і оволоділи навичками та уміннями, необхідними в їх майбутній професії. Лекційні лабораторії оснащені мультимедійними системами для демонстрації навчальних фільмів та презентацій. Лабораторні роботи оснащені відповідною апаратурою, хімічними реагентами і посудом. Позиція керівництва ДДМУ полягає в тому, що якщо нам щось потрібно, то проблема вирішується в найкоротші терміни. Ставлення до студентів доброзичливе, але це не означає, що їм сходять з рук слабкі знання. Ми намагаємося донести інформацію до студентів так, щоб вони засвоїли тї, а не отримали хорошу оцінку тому, що заплатили гроші за навчання. 
Хімічна підготовка майбутніх провізорів $є$ основою формування основних трьох типів компетенцій (загальнокультурних, загально - професійних i професійних), тому треба враховувати місце і роль кожної хімічної дисципліни в системі підготовки провізорів. Наприклад, при вивченні аналітичної хімії звертаємо увагу на те, що ця дисципліна $€$ «містком» довузівської і вузівської етапів хімічної освіти, закладає основи хімічної освіти майбутніх провізорів, бере участь у формуванні хімічних компетенцій як основи загальнокультурних і професійних компетенцій, тому за своєю суттю вони являються професійно орієнтованими. При вивченні фізичної і колоїдної хімії звертаємо увагу на виконання цією дисципліною функції універсальної, інтегративної мови, що дозволяє описувати і вивчати хімічні об'єкти, процеси, методи аналізу.

Високий професійний рівень сучасного фахівця - провізора передбачає володіння хімічними, фізико - хімічними методами аналізу і навичками щодо їх використання. У процесі оволодіння знаннями 3 аналітичної, фізичної та колоїдної хімії закладається теоретична і методологічна база для вивчення фармацевтичних дисциплін, що і складає основу фундаментальної підготовки провізора.

Придбання необхідних хімічних знань, умінь, навичок, що трансформуються в комплекс хімічних компетенцій, як основи майбутнього професіоналізму, створення передумов формування особистісних якостей, які диктуються потребами майбутньої професії - ось, що важливо для підготовки студентів - провізорів до їх подальшої навчальної та професійної діяльності.

Як показали опитування студентів про причини їх неуспішності по деяким хімічним дисциплінам, поряд 3 об'єктивними труднощами їх засвоєння величезний вплив відіграє те, що студент часто погано уявляє собі місце і роль дисциплін у майбутній професійній діяльності.

Методичне забезпечення хімічних дисциплін для студентів - провізорів розроблено на основі компетентнісного підходу, модульності і послідовності викладання навчального матеріалу, що включає робочу програму, дидактичні та контролюючі матеріали і характеризується повнотою і доступністю інформації. 
Такий підхід визначає для студентів - провізорів кінцеві цілі освоєння хімічних дисциплін у вигляді хімічних компетенцій і напрямки їх досягнення (види, способи діяльності, в тому числі самостійної).

У методичних матеріалах до виконання лабораторних робіт значна увага приділяється профілізації викладання в плані ознайомлення студентів 3 фармакопейними методиками аналізу різних лікарських речовин. Кожна лабораторна робота виконується як індивідуальне навчально - дослідне завдання, що дозволяє найбільш об'єктивно оцінювати практичні навички студента провізора. Методичні рекомендації щодо організації самостійної роботи спрямовані на закріплення вміння пошуку, накопичення та обробки наукової інформації

Таким чином, підвищення якості підготовки фахівця неможливо без взаємозв'язку хімічних і фармацевтичних дисциплін, їх інтеграції в процесі навчально - пізнавальної та науково - дослідницької діяльності студентів, важливих для формування їх наукового світогляду і хіміко - фармацевтичної культури. Запорукою успішної реалізації концепції дистанційної освіти $є$ створення інформаційної бази кафедри та своєчасна допомога викладача студентам. Збільшення наочності та спрощена подача матеріалу у вигляді блоксхем сприятимуть не лише покращенню засвоєння матеріалу, а й допоможуть вирішити проблему, пов'язану з протиріччям між об'ємом навчального матеріалу та часом проведення заняття, а також стануть у нагоді при підготовці до підсумкового контролю та екзаменів, що дозволяє підвищити їх практичну значущість та вмотивованість студентів. 